\title{
"I Take Everything Back That I Said": Ambivalence and Motherhood in Mildred Pierce
}

\section{Tine Sommer}

Independent Scholar

\begin{abstract}
This article discusses motherhood in James M. Cain's Mildred Pierce (1941). It argues that academic criticism so far has neglected the important contribution Cain's text makes to debates concerning motherhood norms in the post-Depression years. The article takes as its central concern the fraught relationship between Mildred and her daughter, Veda. Building on Sianne Ngai's theory of "ugly feelings," the article claims that Mildred's ambivalent emotional responses to her daughter reveal how social norms obstruct mothers' agency. Rather than categorically rejecting Veda's bad behavior, Mildred's anger, pain, fear, and jealousy are retracted immediately after they surface. As such, Mildred's maternal emotions are ambivalent and should be perceived as ugly feelings that have the potential to diagnose situations of obstructed agency. This article thus argues for the complexity of Cain's representation of motherhood and shows how mothers' ambivalent emotions reveal limited agency in their navigation of social norms.
\end{abstract}

Keywords: American literature, twentieth century, James M. Cain, Mildred Pierce, motherhood, affect theory

James M. Cain's post-Depression era novel, Mildred Pierce (1941), has never been properly recognized for its nuanced representation of a fraught mother-daughter relationship. While a 1945 Hollywood adaptation of Cain's novel has been the focus of much feminist film criticism since the 1970s, the original novel's more complex narrative has been overlooked. Cain's text, however, makes an important contribution to the debate about motherhood in the post-Depression era that can be discerned through paying close attention to the affects of Mildred's motherhood. In fact, Todd 
Haynes' 2011 adaptation of the novel into an HBO miniseries showcases the continued relevance of Cain's text as it speaks to persisting negotiations of what motherhood should look and feel like, whether in the 1940s or in the twenty-first century. Mildred might at first glance seem like an overprotecting single mother who spoils her daughter, Veda, in order to compensate her employment outside the home. This simple reading of Cain's narrative attributes Veda's awful behavior to Mildred's neglect of her maternal responsibilities and finds in it a warning to women not to abandon their roles as full-time mothers. Yet, this was not Cain's intention. He insisted that Mildred Pierce was about "one woman's struggle against a great social injustice-which is the mother's necessity to support her children even though husband and community give her not the slightest assistance" (quoted in Letort, 262). Accordingly, this article asks: what is, instead, at stake in this narrative of a mother navigating a difficult relationship to her daughter?

Set in 1931, Mildred Pierce deals with the effects of the Great Depression on family life. Mildred's husband, Bert, is bankrupted by the collapse of the real estate market, leaving not only the couple's finances in ruins but also their marriage, as Bert is stultified by his failure and seeks confidence in an extramarital affair. Mildred separates from him and is left alone to support their two daughters. Mildred is thus forced to take a job as a waitress. Trying to alleviate her oldest daughter Veda's disapproval of her new working-class status, Mildred works her way up to start her own successful chain of restaurants. When her younger daughter, Ray, dies, Mildred vows to dedicate "the rest of her life to the child who had been spared" (Cain 125). Mildred worships Veda, whereas Veda treats her mother only with contempt and emotional manipulation. Mildred engages in a romantic relationship with the socialite, Monty. Yet it is Veda, rather than Mildred, who fits in and socializes with his wealthy upper-class friends and family. Mildred subsequently supports Veda's expensive new lifestyle, including her music lessons, based on her "deep, almost religious conviction that Veda was 'talented'" (Cain 11). However, the relationship to Monty turns awry, and, marking a climax in the vexed mother-daughter relationship, Mildred finds Veda in bed with Monty. While at first forgiving Veda, by the end of the novel Mildred finally lets her leave for good and reunites with Bert.

This article argues that to understand Cain's novel it is crucial to ask why Mildred does not clearly reject her daughter's bad behavior and what her emotional ambivalence in relation to Veda means. The quote in the title 
above is characteristic of Mildred's ambivalent mothering: when Mildred occasionally does scold Veda for her terrible behavior and displays strong negative feelings, she takes it back almost immediately and subdues her antagonistic feelings in favor of more normative maternal affects. Employing Sara Ahmed's insistence that "happy objects" shape our lives, this article perceives motherhood in the post-Depression era as socially, culturally, and historically imbued with promises of positive feelings, the good life, and, essentially, with happiness. This trait, in turn, restricts antagonistic emotions in motherhood. However, Mildred's situation is unexpectedly an unhappy one. Veda prompts powerful negative feelings in Mildred which hinder normative affective responses and render Mildred's maternal feelings ambivalent.

Ambivalent feelings can be explored by turning to Sianne Ngai's theory of "ugly feelings." To understand Mildred's failure to reject her daughter's behavior categorically and stand by her negative feelings, it is necessary to look closer at the nature of her ambivalent feelings. Like Ngai's "ugly" feelings, ambivalence can be seen as a weak, less noble, and a somewhat negative feeling. As Ngai explains, these characteristics make it possible to diagnose situations of obstructed agency. Adding to Ngai's catalogue of ugly feelings, then, Mildred's maternal ambivalence has the same critical potential. Indeed, I find that ugly feelings are crucial for discussions of representations of motherhood because ambivalence reveals how social norms limit mothers' agency, especially in times when gender roles are challenged.

\section{Mildred Pierce film criticism}

As mentioned, Cain's Mildred Pierce has received very little critical attention since its publication, and the sparse criticism it has fostered focuses on other aspects of the text than this article. ${ }^{1}$ While Cain's more well-known crime novels, such as The Postman Always Rings Twice (1934) and Double Indemnity (1943), have been the focus of literary criticism centered on the masculinized hard-boiled genre Cain epitomized, Mildred Pierce has no crime plot and, consequently, has been largely overlooked by Cain schol-

1 Campbell and Robison, almost the only scholars that have taken seriously Cain's novel as their topic of literary criticism, both discuss Mildred Pierce as Cain's critique of the economic effects of the Great Depression. 
ars. However, from the late 1970s onward, Michael Curtiz' 1945 film noir adaptation of Cain's novel, in which a murder was added as central to the plot, has fostered much feminist film criticism, some of which focused on Mildred as a post-war mother and which serves to highlight the difficulty critics have had with explaining Mildred's motherhood. This critique is relevant for Cain's text as well. Many of the first feminist critics of Curtiz' film discussed its curious position in-between melodrama and film noir. They saw the film as an example of the post-war period's social control where working mothers were supposed to refocus their attention to home and family as American soldiers returned from war and reclaimed "their" jobs. ${ }^{2}$ Pam Cook (1996) importantly argued that the film mixed film noir with melodrama in a way that undermined the female voice and authority. June Sochen stated that Curtiz' film "acted as a piece of social control for women" who were warned against having too high ambitions for themselves and their daughters (9). Hence, Sochen argued, the film demonstrated that women leaving the home would endanger the American family.

A little less categorically, Lloyd and Johnson's argument that the film "actively explore[s] a tension between discourses of modernity and femininity," rather than merely polices women, comes closer to my own interpretation of Cain's novel (7). They see the film as conveying how Mildred must become a "modern citizen" by navigating both the public world of work and her feminine identity (Lloyd and Johnson 7). Lloyd and Johnson further argue that the film's merging of film noir and melodrama "complicates simplified notions of maternal sacrifice" as it was usually conveyed in Hollywood pre-World War II cinema: "This new post-war development indicates that rather than a clear separation of good and bad mothers, these discourses could be embodied in one character at different times" (Lloyd and Johnson 16). However, Lloyd and Johnson's convincing argument, relevant also for Cain's text, lacks the more specific investigation of maternal affects and Mildred's ambivalence that is so important for understanding the complexity of Cain's representation of motherhood. Cook has stated that the film's ending "makes it explicit that Mildred's possessive love for Veda is largely to blame for the tragic events" and "provides closure [that] is absent from the novel" (Cook 2013 381). Indeed, the novel is more nuanced than the film and provides no such simplified closure. Cain's text, 
instead, pushes against the prevalent tendency in post-Depression discourse to police working mothers. The fundamental difference between Curtiz' version of Mildred Pierce and Cain's novel, in fact, rests in the degree of complexity: Whereas the black-and-white film simplifies Cain's representation of motherhood by making Veda a murderess and by clearly blaming Mildred for her failure to comply with normative motherhood, the novel, as Cain himself insisted, seeks to portray in a less binary manner Mildred's predicament as a mother in a precarious situation.

\section{Post-depression motherhood}

In the post-Depression era, before the war-production years set in, motherhood norms were under pressure from an array of changes. Women's suffrage, and increased education levels, as well as middle-class women's participation in the paid work force during the Depression contributed to making motherhood the topic of intense debate. From concerned mothers' letters in women's magazines, through New Deal legislation and debates about day care, to childrearing experts' advice, motherhood discourse conveyed what seemed a pervasive anxiety about motherhood's role in an unstable world. ${ }^{3}$ As a consequence, the roles that had defined "good" mothers since the Victorian age ${ }^{4}$ were reinforced in the arguments of maternalists in the first decades of the twentieth century and again in discourses about daycare during the Depression years ${ }^{5}$. These discourses conveyed that mothers naturally loved, and selflessly devoted all their time and attention to their children who in turn would grow up to become good American citizens, promising stability and prosperity for the nation.

Cain's narrative both represents and negotiates middle-class life as many Americans experienced it during the 1930s. Mildred Pierce mirrors the con-

3 See for instance Laura L. Lovett's discussion of the American family's "state of crisis" in the first decades of the twentieth century (7) or Mink's discussion of the New Deal WPA program that only employed women who were not mothers. Elizabeth Rose discusses how the lack of day care in the New Deal Era was a consequence of a refusal to accept mothers as providers.

4 As several scholars have shown, most importantly Barbara Welter, the notion of true womanhood in the nineteenth century defined women as domestic, maternal, and moral. They were thus perceived as responsible for ensuring stability and a prosperous future for the nation through their managing of husbands and raising good future American citizens.

5 See for instance Ladd-Taylor and Umansky who show that maternalists in the 1910s and 20s argued that "women were uniquely suited to nurture and care" as an argument for women's greater political influence (11). Rose shows that the Depression years saw a "more focused and vigorous" "hostility toward married women's employment" (96). 
sequences of the Great Depression for middle-class family life, as many fathers and husbands lost their jobs and were no longer able to be the main provider for their families. Consequently, increasing numbers of previously unemployed middle-class women had to enter the workforce. As was typical for women in this situation, Mildred has not learned any skills or received any higher education and is therefore forced to settle for a low-paying position as a waitress, which resembles the unpaid housework she has previously done. Mildred Pierce's central theme, the mother-daughter relationship, should therefore be perceived as addressing the anxieties and concerns that working mothers fostered in the period of the novel's publication.

\section{Motherhood as happy object}

This discourse in the 1930s positions motherhood as what affect theorist Sara Ahmed has called a "happy object." Ahmed explains that certain objects promise happiness and thus shape norms, group formations, and identities: "Certain objects become imbued with positive affect as good objects" and "perceived as necessary for a good life" ("Happy Objects" 34). As such, happy objects prompt orientation towards them as they form and stabilize group belonging:

Groups cohere around a shared orientation toward some things as being good, treating some things and not others as the cause of delight. If the same object makes us happy-or if we invest in the same objects as being what should make us happy-then we would be orientated or directed in the same way. (Ahmed, "Happy Objects" 35)

Consequently, perceiving motherhood as a happy object reveals its importance to not only individual women but to class- and identity formation. Ahmed, indeed, notes affects' importance in "shap[ing] the 'surfaces' of individual and collective bodies" (Cultural Politics 1). Ahmed stresses that what is at stake in the pattern of affectively orientating towards shared happy objects is the sense of belonging to a group: "When we feel pleasure from objects, we are aligned; we are facing the right way. We become alienated-out of line with an affective community - when we do not experience pleasure from proximity to objects that are already attributed to being good" ("Happy Objects" 37). Because motherhood is positioned as essential to middle-class belonging, individual happiness, and American stability, failure to comply with the scripted affects for motherhood is not an 
option. However, this poses a problem in Mildred Pierce: How can Mildred react according to the script as a single working mother with a daughter that disrupts motherhood's promises of positive feelings, the good life, and good citizenship?

What happens in the situations where a negative affective atmosphere arises between mother and daughter? Veda's cruel and selfish responses to Mildred's insistent motherly love unsurprisingly prompt antagonistic emotions in Mildred that are, however, subdued by affirmative emotions. Accordingly, Mildred's negative feelings become ambivalent and "ugly" rather than powerful and a cause for rejection. Instead of expressing clearly her fear, pain, jealousy, and rage, Mildred repeatedly retracts these feelings, making them, in turn, weak and diffuse, and depriving them of power. As such, strong antagonistic emotions turn "ugly" because motherhood norms restrict what mothers are supposed to feel.

\section{Ugly feelings}

Just as affects can form and sustain normative attachments to motherhood, affects are also useful in discussions of resistance to norms. Bringing the theory of ugly feelings' critical potential to bear on Mildred Pierce reveals how Mildred's ambivalent emotional responses to her daughter convey motherhood norms' obstruction of mothers' agency. According to Sianne Ngai, ugly feelings can be characterized as negative affective responses that are less intentional, less directed toward an object, and less motivating than the "philosophically canonical emotions" and the "grander passions" that act as catalyzers for action in tragic drama $(11,6)$. Ugly feelings are marked as negative in the sense that they "evoke pain or displeasure" and are "saturated with socially stigmatizing meanings and values" (Ngai 11). Accordingly, Ngai defines ugly feelings as minor, negative, and less prestigious emotions that are ambiguous. Ugly feelings, Ngai states, "both originate from and reflect back upon" a situation of passivity (12). Despite (and, indeed, because of) their diluted nature, ugly feelings can potentially "diagnose situations" of "blocked or thwarted" action "with respect to other human actors or to the social as such" where the appropriate emotional response should be stronger (Ngai 6, 27, 3).

The same is the case for the ambivalence conveyed in Mildred Pierce's retraction of her powerful negative emotions in favor of maternal affection. While Mildred does at times respond to Veda with strongly negative emo- 
tions, they are repeatedly appeased and, consequently, become harmless, ambiguous, and ugly. This pattern reveals how strong negative emotions that are not welcome in the cultural narrative of motherhood as a happy object are overruled by the more suitable maternal devotion Mildred also feels. The cultural incentive to perceive motherhood as the cause of good feelings and a happy life hinders Mildred's ability to recognize and act on her negative emotions. Ambivalence in representations of motherhood, such as in Mildred Pierce, should thus be perceived as having the same critical potential as ugly feelings. While Ngai's overarching argument specifically has to do with the limitations to the agency of art in a capitalist and commodified society, ugly feelings' diagnostic potential is certainly also useful for describing the obstruction of the agency of people, in this case, mothers, by social circumstances.

\section{Ambivalence in Mildred Pierce}

The antagonistic and traditionally powerful emotions, anger, pain, fear, and jealousy, that Veda fosters in Mildred are throughout Cain's text conveyed as temporary and ambivalent. They are conveyed as in conflict with and repeatedly overruled by the positive and socially acceptable maternal emotions Mildred also has. Rather than prompt her to reject Veda for her malicious behavior, Mildred's strongly negative emotions leave her stunted. In fact, many times they only reinforce Mildred's efforts to please Veda in a denial of her unpleasant and unexpected feelings. Mildred can only allow herself the positive feelings that motherhood as a happy object has made available and, hence, her potentially powerful emotions turn ugly.

It is important to note that Cain's focus is on Mildred's emotions and that he leaves Veda's behavior largely unexplained. One critic of the film adaptation, C. M. Gill is probably right when she argues that Veda's "avarice" is a result of her triangulation in the "recurrent negative patterns" and "dysfunctional nature" of the Pierce family $(91,88)$. Whatever the underlying psychological reason might be, Cain's text clearly creates a family situation which in multiple ways is marked by a negative affective atmosphere: Bert's inertia and inability to support his family, Mildred and Bert's disagreements and separation, and, of course, the death of Veda's younger sister, Ray, could all count as reasons for Veda's acting out. Yet it is the un- 
expected unhappy family situation Mildred finds herself in that is important for the narrative. Cain makes explicit that Veda has a "cold, cruel, coarse desire to torture her mother, to humiliate her, above everything else, to hurt her" (79). Consequently, motherhood in this narrative cannot live up to its promises of love, purpose, and happiness.

While Mildred in glimpses does recognize this situation, Cain's text conveys that she chooses to believe that she and Veda shares a normal loving mother-daughter bond. The narrator thus states: "Mildred yearned for warm affection from this child [...] But all she ever got was a stagy, affected counterfeit. This half loaf she had to accept, trying not to see it for what it really was" (79). Mildred has to accept Veda's fake affection because her identity is circumscribed by the positioning of motherhood as a happy object. However, the discrepancy between Veda's cruelty and the happiness promised to mothers forges Mildred's ambivalent affective responses and reveals her limited agency.

Fear and pain are two prominent negative feelings in Mildred's response to Veda's cruelty that turn ugly in text. Fear could enable its subject to flee a threatening situation. However, in Mildred Pierce it stunts Mildred. Likewise, pain has the potential to motivate rejection and reorientation away from the painful object, as Ahmed has argued, but never fulfills that potential for Mildred. ${ }^{6}$ Moreover, Mildred's fear and pain are always temporary and relieved by other more comfortable feelings. As such, they should be seen as a sign of ambivalence caused by Mildred's refusal to recognize other emotions than the positive ones motherhood as a happy object has promised her. Fear and pain do not prompt Mildred to reject, or openly oppose, Veda and her behavior but function as ugly feelings that diagnose mothers' situation as one of immobility, barred from antagonistic feelings and, as a consequence, from recognizing and acting against harm. In a similar pattern, strong anger and, at one point, even hatred become ambivalent and "ugly" as Mildred denies these feelings when they emerge in favor of positive ones. In fact, another of Mildred's negative emotions, jealousy, marks this duality of feelings. As a powerful emotion traditionally utilized in narratives to spur action between lovers, jealousy conveys love through a negative expression and is thus, in itself, an ambivalent feeling. 


\section{I take back my anger and pain}

Whereas Sianne Ngai has discussed irritation as an ugly feeling of "incorrect or 'inadequate' anger," in Mildred Pierce, anger becomes ugly because it turns ambivalent (175). As Ngai argues is the case with irritation, the ambivalence that characterizes Mildred's anger reduces it to a "minor" less intense negative affect, an "ugly" feeling (174). A key example of how Mildred's, clearly justified, anger at Veda is temporary and diluted by her retraction and reformulation of "fury" into maternal devotion is found in a passage where Bert has come home to pick up his things after having moved out. Previously, Mildred's neighbor Mrs. Gessler has gifted Mildred a bottle of bootleg whiskey with the purpose of providing a pleasant night that can land her a new male provider in the form of Bert's former business partner, Wally. However, against Mrs. Gessler's advice about holding out, Mildred sleeps with Wally and saves the bottle, thinking that she might be able to sell it. The unopened bottle of whiskey thus has a double meaning in the text: as a symbol of Mildred's intent to support herself and her children without a husband and as an object of higher monetary value than Mildred's body, signifying Mildred's dire financial situation. Consequently, this specific bottle of whiskey is saturated with emotions. However, without asking Mildred and with an air of deliberate provocation, Veda offers her father the Scotch when he visits: "Aren't you terribly thirsty, Father? Mother, would you like me to open the Scotch?," Veda asks pretending innocence (59). Put on the spot like this, Mildred's anger with her daughter is impossible to repress:

Mildred was as furious as she ever permitted herself to get at Veda. It was the same old Scotch, and she had been saving it against that dreadful day when she might have to sell it, to buy bread. That Veda even knew it existed, much less how to open it, she had no idea. And if it was opened, that meant that Bert would sit there, and sit there, and sit there, until every drop of it was gone, and there went her Scotch, and there went her evening. (59)

Realizing her Scotch is "doomed," Mildred goes to fetch it from her bedroom closet. Veda follows and Mildred confronts her in the dialogue as follows:

"Who asked you to go snooping around my closet to find out whether there was any liquor there or not?"

"I didn't know there was any secret about it."

"And hereafter, I'll do the inviting."

"But Mother, it's Father." 
"Don't stand there and look me in the eye and pretend you don't know what I'm talking about. You know you had no business saying what you did, and you knew it at the time, I could tell by the cheeky look on your face."

"Very well, Mother. It shall be as you say."

"And stop that silly way of talking."

"But I remind you, just the same, that there was none of this kind of stinginess when Father was doing the inviting. Things have indeed changed here, and not for the better, alas! One might think peasants had taken over the house."

"Do you know what a peasant is?"

"A peasant is a - very ill-bred person."

"Sometimes, Veda, I wonder if you have good sense."

Veda stalked out, and Mildred grimly arranged the tray, wondering why Veda could put her so easily on the defensive, and hurt her so. (59-60)

The passage conveys Mildred's anger and pain at Veda's behavior and also clearly shows Veda's conscious effort to manipulate and hurt her mother. Veda's awareness of her mother's hiding the bottle makes her offering it to her father an act of deliberate malignance or provocation designed to hurt her mother. Cain thus represents Veda as a character that should foster antagonistic emotions. However, Mildred can only "permit" herself a certain amount of fury because she is constrained, and indeed defines herself, by the norms that follow the notion of motherhood as a happy object.

Consequently, while Mildred briefly is both furious, frustrated, and feels hurt, she quickly takes back her scolding of Veda, rejecting her antagonistic emotions and second-guessing her response to the situation. Bert indeed stays and drinks the whiskey but the scene ends with him letting Mildred have their car, which she desperately needs for work. Choosing to see Veda's interfering as the cause of this positive turn of events, Mildred turns her anger and hurt into praise as she tells Veda: "Something very nice happened tonight, and you were the cause of it all, and I take everything back that I said" (67). Taking back everything, Mildred's justified anger and pain are thus retracted and her response to Veda's bad behavior thus becomes ambivalent. Having only briefly transgressed the feelings prescribed by the notion of motherhood as happy object, Mildred stabilizes her normative identity as a mother by aligning with the notion of maternal devotion and the expectation that children are the source of happiness.

In the passage, Mildred's anger and pain at Veda's deliberate provocation do not foster any real action or rejection. Rather, Mildred converts the situation into an affirmative one that fosters good feelings. However, other situations are harder to dismiss for Mildred. When Veda fakes a pregnancy 
in order to blackmail a wealthy family, Mildred is "consumed by a fury so cold that it almost seemed as though she felt nothing at all. It didn't occur to her that she was acting less like a mother than like a lover who has unexpectedly discovered an act of faithlessness, and avenged it" (225). While Mildred's cold fury and her revenge when she throws Veda out at this point tellingly marks her as not a mother (but as a lover, a point that is dealt with at a later point in this article), anger here does, at least temporarily, enable Mildred to act. The passage's notion that Mildred's fury is cold and like feeling "nothing at all," conveys how difficult it is for Mildred to transgress the normative expectations for maternal emotions. At risk of identifying as non-mother, Mildred eventually has to find a way back to affirmative feelings and normative motherhood. Consequently, when Mildred six months later finds out where Veda lives, "[e]very fiber of being had wanted to pay a visit there, to take back what she said, to re-establish things as they had been, or try to" (226). Mildred here again seeks to retract her anger, making a strong negative feeling ambivalent as "every fiber" of her wishes to undo the action anger temporarily enabled and re-establish a normative form of mothering.

Not having contact with Veda for six months, this passage shows, only intensifies Mildred's attempts to create affection between them. Another instance in the text where this is the case is when Veda is left devastated having been told that she has no future as a piano player. She reacts to Mildred's attempts to comfort her by, first, screaming at her and, then, throwing a shoe at her. Rather than allowing herself to be comforted by her mother, Veda rejects and insults her, calling Mildred a "damned, silly-looking cluck" and a "punk" (202). While these insults do not seem to have any particular effect on Mildred, what eventually hurts her is that Veda proceeds to ignore her, apathetically lying in her bed staring at the ceiling:

To have her scream at her was painful, but bearable, for at least it was she that was being screamed at. To have her lying there on the bed, staring at the ceiling, and not even thinking about her, was an agony too great to be borne. Even as she was trying to be detached [...] she was deciding that where Veda really belonged was in the pictures [...]. (205)

Because Mildred cannot bear the pain, she cannot leave Veda alone. She convinces herself that Veda could become an actress instead of a piano player and starts to imagine how to effectuate that plan. However, Veda eventually does reestablish contact with her mother because she needs money and 
Mildred never has to act on her new plan. Nevertheless, it is clear that the pain motherhood fosters for Mildred only causes her to intensify her efforts to create a normative mother-daughter attachment. Because agony in the way Mildred feels it here (as a result of her daughter's rejection) is too strongly negative for normative motherhood, Mildred appeases it by trying new ways of pleasing her daughter. In Mildred Pierce's motherhood, strong pain does not cause rejection of, or orientation away from, the painful object but, rather, becomes diffuse and weak: an ugly feeling resulting from the lack of agency norms for motherhood entails. The notion of motherhood as a happy object and, accordingly, the imperative for women to align with it is shown as stultifying through the turning of traditionally powerful negative emotions into ambivalent ugly, diffuse and unfocused, ones.

At a later point in the text, when Mildred for once refuses to be the one to reestablish contact with Veda after a major argument, Mildred's pain is described as even more excessive, compared to cancer and as the cause for her drinking. However, even this cancerous destructive pain becomes ambivalent because Mildred relieves it by fantasizing about forgiving Veda and deprives the strongly negative emotion of its disruptive potential:

And yet, even in her loneliness, her relation with Veda was developing, twisting her painfully, like some sort of cancer. She discovered rye, and in her boozy dreams of her daily rest, she pictured Veda as going from bad to worse, as hungering and mending threadbare finery, until she had to come back, penitent and tearful, for forgiveness. (226)

Pain is drowned in booze here and converted into fantasies of a devoted repentant daughter aided by her strong and nurturing mother. Negative pain is again sought subdued as it has no place in normative motherhood and, therefore, loses its potential to foster disruptive action. Pain, like anger, when felt in motherhood, the text conveys, is ambivalent at most and, as such, pain embodies the same characteristics as ugly feelings do. Recognizing Mildred's pain and anger as ugly feelings, as ambivalent rather than powerful, exposes Mildred's situation as one of obstructed agency. Consequently, Cain's text can be seen to criticize the destructive nature of the imperatives of motherhood as a happy object with its insistence on the unbreakable and affirmative attachment between mother and child. 


\section{Fear and immobility}

As is the case with anger and pain, the power that fear could have is reduced for Mildred as a mother. Rather than cause her to question or reject the norms that require unconditional maternal devotion, fear obstructs any action. Ngai calls fear "an expectant emotion" with "anticipatory character" (210). According to Ngai, anxiety is fear's equivalent ugly feeling because it is a diluted form of fear that has no object. Anxiety thus hinders its subject from taking action against an object in the way fear would. Of course, Mildred's ambivalent fear does have an object. Yet because Mildred refuses to recognize and act on her fear and because she quickly retracts it in favor of her positive feelings, ambivalent fear also becomes diluted, unfocused, and ugly. Consequently, Mildred's ambivalent expression of fear exposes Mildred's limited agency as a mother circumscribed by expectations and norms of happy motherhood.

From early on in the text it is clear that Mildred is afraid of her daughter and what she represents:

She was afraid of Veda, of her snobbery, her contempt, her unbreakable spirit. And she was afraid of something that seemed always lurking under Veda's bland, phony toniness: a cold, cruel, coarse desire to torture her mother, to humiliate her, above everything else, to hurt her. (79)

Throughout the narrative it is apparent that Mildred's fear is justified as Veda continuously seeks to cause her mother pain. However, Mildred tries to alleviate her fear by bestowing Veda with love and material goods that she thinks will satisfy her. When she cannot afford to buy Veda a new piano for Christmas as promised and instead gives her a less expensive watch, fear surfaces on Mildred's body:

Mildred licked her lips, opened her mouth to make explanations, but at the cold look on Veda's face, she couldn't. Nervously she said something about there being a great many presents [...] When [Veda] got her wrist watch she examined it with casual interest, laid it aside without a comment. At this Mildred went back to her bedroom, lay down on the bed, tried to stop trembling. The trembling went on. (167)

While the object of Mildred's fear here is clearly Veda, fear causes Mildred to tremble rather than act. The passage's explicit description of Mildred's licking her dry lips and trembling makes Mildred's fear tangible to the reader. In this way, the text forces attention to Mildred's overall immobility, not 
being able to speak and, instead, retracting to her bedroom to lie motionless on her bed. This combination of a distinct rendering of Mildred's fear of Veda with her inability to act against her, makes very clear that strongly negative feelings in motherhood do not prompt action. Instead, they become ambivalent and diluted as they are questioned and sought relieved and, in this way, they restrict any agency.

\section{The power of jealousy?}

In the chapter on anger and pain, a text passage from Mildred Pierce stated that Mildred was "acting less like a mother than like a lover," seeking revenge for Veda's infidelity. Indeed, it is a recurring theme throughout the narrative to render Mildred's maternal affects erotic. An interesting discussion of this theme is found in Robert J. Corber's analysis of Mildred's “incestuous desire" for Veda in Curtiz' film (7). Corber here notices an "unresolved perversity" in their relationship (14). Mildred's desire for Veda disrupts the nuclear family's normative "oedipal structure" as Mildred wants to take on both the paternal and maternal role for Veda and "replace Bert as head of the family" (Corber 24, 16). Corber concludes that Mildred is in fact cast as the hard-boiled film noir hero and Veda as the femme fatale who betrays the hero.

The strongly erotic affects between Mildred and Veda are certainly also present in the novel. However, I read these as adding to Cain's representation of maternal confusion and Mildred's inability to live by norms for maternal behavior in her modern situation. While I will not delve deeper into this specific topic here, Mildred's erotic maternal emotions can be understood to expose the norms for motherly love through her hyperbolic performance of these, much in the same way as Judith Butler's seminal argument about drag performances, sexuality, and gender. ${ }^{7}$ Mildred's shocking erotic love for Veda forces attention to the nature of her maternal emotions. The hyperbolic erotic maternal affects stand in stark contrast to Mildred's strong negative feelings. Together, these two extremes underline Cain's critique of

7 Butler argues in "Critically Queer" that hyperbolic performances of gender, such as drag performances, can be potentially disruptive to gender norms (which are themselves a consequence of a "compulsory repetition") as they make visible the "taken-for-granted quality of heterosexual performativity" (23, 27). Mildred's maternal love becomes hyperbolic as it takes on erotic qualities. As such, motherhood norms are exposed as constructed rather than "natural." 
unobtainable norms for motherhood and its power as a happy object which focuses all of Mildred's attention to performing motherhood correctly and which destroys other valuable romantic relationships in her life. As the description of Mildred as a lover seeking revenge conveys, jealousy is yet another negative emotion in Mildred's motherhood.

Like other strongly negative emotions, jealousy traditionally forges some kind of action. Whereas Ngai discusses envy as jealousy's ugly equivalent, in Mildred Pierce it is jealousy itself that turns ugly. Envy, while clearly directed toward an object, is confusing as to whom or what it belongs, Ngai argues. In this way, envy hinders action because it, like other ugly feelings, is diffuse and confusing. Mildred's jealousy at Veda, in somewhat the same manner, is ugly because it is repeatedly withdrawn, alleviated, and questioned. As a textual example, Cain's novel conveys that even though Mildred feels "profoundly miserable, almost physically sick" when she learns from a friend that Veda is picking up men at bars at the age of seventeen, she "conscientiously" tries to accept Veda's false assurance that she is platonically getting to know directors who can help her acting career (207). Mildred's physical reaction to the insinuation that the young Veda is sexually active suggests a painful jealousy. Yet, rather than act, she tries to alleviate the feeling by denying it and replacing it with maternal trust in her daughter's benign intentions.

In another passage, Mildred's jealousy when Veda claims she is pregnant is also described as making her physically ill: "For a second the jealousy was so overwhelming that Mildred actually was afraid she would vomit" (213). While the text is not clear here, Mildred's jealousy seems aimed at either the baby, whom Veda would supposedly love and nurture, or its father who has had intimate relations with Veda. Either way, Mildred's jealousy stands out here as it, again, reveals the difficulty she has with doing motherhood correctly. The powerful effects such jealousy could have had on Mildred's ability to act against Veda, however, are never set in motion. Instead, when Veda fakes remorse about getting pregnant and leans her head on her mother's shoulder, Mildred's "sick feeling" of jealousy disappears (213). In fact, jealousy is alleviated by what could resemble orgasmic pleasure: "a tingle went through Mildred. She gathered Veda to her bosom, held her tight, patted her, cried a little" and "closed her eyes for a moment, to savour this sweet blandishment" (213). However, although temporarily alleviated through physical contact with Veda, the jealousy is insistent as a "great pain" that keeps Mildred awake: "All through the night, Mildred 
kept waking with the jealousy gnawing at her" $(215,214)$. The ambivalence jealousy thus entails, the simultaneous feelings of physical disgust and pleasure, makes it "ugly," diffuse and confusing, and leaves Mildred awake but unable to act.

Mildred's jealousy at another pivotal point in the narrative does seem at first to foster conclusive action. Mildred's rage forces her to physically act when she finds Veda in bed with Monty, Mildred's second husband. Focusing on her daughter rather than her husband, Mildred's "mind was on the lovely little thing in the bed, and again she was physically sick at what its presence there meant" (274). As Veda gets out of bed, "Mildred leaped. But it wasn't at Monty that she leaped, her husband, the man who had been untrue to her. It was at Veda, her daughter, the girl who had done no more than what Mildred had once said was a woman's right" (275). Apart from the obvious erotic implications of the situation, Mildred is enraged, physically sick from what Veda has done, and acts on her rage by "leaping" at her like an animal. The text indicates that it is Veda who has been "untrue" to Mildred. Indeed, the image of a daughter sleeping with her mother's husband (the equivalent of a father) is the ultimate sign of rejection of any family-bond between mother and daughter, and it seems that this is what Mildred reacts against in this passage. The antagonism between mother and daughter is so strong that it becomes physically visible on their bodies at this point as "hatred that twisted their faces" (276).

Astonishingly, even this extreme anger and hatred, fostered by Mildred's jealousy, is temporary and without decisive consequences for her motherhood. Despite the undeniable marks that the incident leaves on Mildred, what the text describes as "a scar on her soul that she thought nothing could ever heal [...]," Mildred forgives her daughter quite easily (277). She is thus "weepily grateful" when Veda arranges a reunion with her for the sake of the press. Because Veda pretends that Mildred's attempt to strangle her has damaged her singing voice, incredulously Mildred feels that "[s]he had done Veda a wrong [...]" and has to "atone" (278). In her head, Mildred again focuses on how to nurture, please, and provide for Veda. At this point, almost at the end of the novel, the narrator underlines Mildred's tendency to retract her antagonistic feelings as it is dryly stated: "Here again was a familiar emotional pattern, with new excuses" (278). Indeed, the familiar pattern Mildred follows has her consistently retract her antagonistic emotions so they become less powerful. This tendency marks Mildred's negative feelings as ambivalent and, thus, "ugly" and, in turn, exposes how motherhood obstructs agency as it prescribes certain emotions and bans others through its promises of happiness. 
While Mildred, by the end of the text tearfully defeated, reluctantly repeats Bert's proclamation about Veda, "To Hell with her!," this cannot be read as a sign that she has finally transgressed the boundaries of normative motherhood and rejected her harmful daughter (281). It is in fact Veda who leaves Mildred for good by the end of the text and Mildred is merely seeking to cope with this fact. As the analyses of Mildred's ambivalence above have shown, strongly negative feelings in Mildred's motherhood are reformulated as ambivalent "ugly" feelings in Cain's text. They become diluted and diminished by their retraction and their replacement by normative maternal emotions and behaviors. The ambivalence this reveals should be perceived in the same way that the "ugly" feelings Sianne Ngai has discussed expose situations of obstructed agency and social powerlessness. The representation of ambivalence in the text thus exposes the precarious situation Mildred is in as a mother submitted to norms that call for affirmative feelings and selflessness when Veda clearly prompts antagonistic responses. The powerful negative emotions Mildred briefly exhibits are, however, socially stigmatizing in the framework that is offered by motherhood's position as a happy object. Cain thus shows how post-Depression motherhood, anxiously policed in an attempt to alleviate pressures on traditional gender roles, prohibits strong negative feelings. Recognizing instances where such feelings are denied and, instead, become ambivalent enables a more complex understanding of literary representation of motherhood. 


\section{Works Cited}

Ahmed, Sara. "Happy Objects." The Affect Theory Reader, edited by Melissa Gregg and Gregory J. Seigworth. Duke University Press, 2010, pp. 29-51.

. The Cultural Politics of Emotion. Edinburgh University Press, 2004.

Butler, Judith. "Critically Queer." GLQ: A Journal of Lesbian and Gay Studies, vol. 1, no. 1, 1993, 17-23.

Cain, James M. Mildred Pierce. 1941. Phoenix, 2011.

Campbell, Donna M. "Taking Tips and Losing Class: Challenging the Service Economy in James M. Cain's Mildred Pierce." The Novel and the American Left: Critical Essays on Depression-Era Fiction, edited by Janet Galligany Casey. University of Iowa Press, 2004, pp. 1-15.

Cook, Pam. "Beyond Adaptation: Mirrors, Memory, and Melodrama in Todd Haynes's Mildred Pierce." Screen, vol. 54, no. 3, 2013, pp. 378-387.

. "Duplicity in Mildred Pierce." Women in Film Noir, edited by E. Ann Kaplan. 1978. BFI Publishing, 1998, pp. 69-80.

Corber, Robert J. "Joan Crawford's Padded Shoulders: Female Masculinity in Mildred Pierce." Camera Obscura 62, vol. 21, no. 2, 2006, pp. 1-31.

Curtiz, Michael, director. Mildred Pierce. Warner Bros., 1945.

Gill, C. M. "Martyring Veda: Mildred Pierce and Family Systems Theory." Style, vol. 44, no. 1-2, 2010, pp. 81-98.

Haralovich, Mary Beth. "Too Much Guilt is Never Enough for the Working Mother: Joan Crawford, Mildred Pierce, and Mommy Dearest." The Velvet Light Trap, Number 29, 1992, pp. 43-52.

Haynes, Todd, director. Mildred Pierce. HBO, 2011.

Ladd-Taylor, Molly, and Lauri Umanski, editors. 'Bad' Mothers: The Politics of Blame in Twentieth-Century America. New York University Press, 1998.

Letort, Delphine. "First Glances at Mildred Pierce: Adapting Hardboiled Melodrama." Screen, vol. 56, no.2, 2015, pp. 262-8.

Lloyd, Justine and Lesley Johnson. "The Three Faces of Eve: The Postwar Housewife, Melodrama, and Home." Feminist Media Studies, vol. 3, no. 1, 2003, pp. 7-25.

Lovett, Laura L. Conceiving the Future: Pronatalism, Reproduction, and the Family in the United States, 1890-1938. University of North Carolina Press, 2007.

Mink, Gwendolyn. The Wages of Motherhood: Inequality in the Welfare State, 1917-1942. Cornell University Press, 1995.

Ngai, Sianne. Ugly Feelings. Harvard University Press, 2005.

Robertson, Pamela. "Structural Irony in Mildred Pierce, or How Mildred Lost Her Tongue." Cinema Journal, vol. 30, no. 1, 1990, pp. 42-54.

Robison, Lori. “'The Lamp in Mildred's Living Room”: Cain's Mildred Pierce and Veblen's Conspicuous Consumption." Papers on Language and Literature, vol. 52, no. 3, 2016, pp. 255-290.

Rose, Elizabeth. A Mother's Job: The History of Day Care, 1890-1960. Oxford University Press, 1999.

Scheman, Naomi. "Missing Mothers, Desiring Daughters: Framing the Sight of Women." Critical Inquiry, vol. 15, no. 1, 1988, pp. 62-89.

Sochen, June. "Mildred Pierce and Women in Film." American Quarterly, vol. 30, no.1, 1978, pp. 3-20.

Welter, Barbara. "The Cult of True Womanhood: 1820-1860.” American Quarterly, vol. 18, no. 2, 1966, pp. 151-174.

Williams, Linda. “'Something Else Besides a Mother': Stella Dallas and the Maternal Melodrama." Cinema Journal, vol. 24, no. 1, 1984, pp. 2-27. 